\title{
Purpura Fulminansın Nedeni Lamotrijin mi?: Olgu Sunumu
}

\author{
Is Lamotrigine the cause of Purpura Fulminans?:Case Report \\ Fatma Şimşek ${ }^{1}$, Revza Tosunoğlu ${ }^{1}$, Büşra Solak ${ }^{2}$ \\ ${ }^{1}$ Atatürk Üniversitesi Tip Fakültesi Nöroloji Anabilim Dal, Erzurum \\ ${ }^{2}$ Atatürk Üniversitesi Tip Fakültesi Dermatoloji Anabilim Dalı, Erzurum \\ Yazışma Adresi / Correspondence: \\ Fatma Şimşek \\ Atatürk Mah, Atatürk Üniversitesi. Posta kodu:25240 Yakutiye/Erzurum \\ T: +90505 $8347780 \quad$ E-mail: klamaks@hotmail.com \\ Geliş Tarihi / Received : 05.12.2020 Kabul Tarihi / Accepted : 03.04.2021 \\ Orcid: \\ Fatma Simșek https://orcid.org/0000-0003-1662-5534 \\ Revza Tosunoğlu https://orcid.org/0000-0002-2675-0825 \\ Büşra Solak https://orcid.org/0000-0002-6809-9399 \\ ( Sakarya Tip Dergisi / Sakarya Med J 2021, 11(2):442-446) DOI: 10.31832/smj.835905
}

Öz

Purpura fulminans çoğunlukla enfeksiyonlara sekonder ortaya çıkan ve mortalitenin yüksek olduğu bir sendromdur. Yaygın damar içi pıhtılașmayla doku ve organ nekrozuna neden olabilmektedir. Ölümler genellikle multisistemik tromboz ya da septik şok kaynaklıdır. Etiyolojik nedenin huzlıca bulunarak tedaviye başlanması hayati öneme sahiptir. Purpura fulminans nadiren ilaç kullanımı sonrasında da ortaya çıkabilmektedir. Lamotrijin de ciddi deri reaksiyonlarına neden olduğu için ilaca başladıktan sonra olușan döküntüler dikkatle takip edilmelidir. Burada lamotrijin bașlandıktan 20 gün sonra döküntüleri gelișen fakat lamotrijinin değil enfeksiyonun neden olduğu purpura fulminans vakasını sunuyoruz. Bu olgu lamotrijinin ciddi cilt reaksiyonlarına sebep olsa da görülen her döküntüde suçlanmaması gerektiğine dikkat çekmek için sunulmuştur.

Anahtar Lamotrijin; Purpura fulminans; Streptecoccus pneumonia

kelimeler

Abstract

Purpura fulminans is a syndrome that mostly occurs secondary to infections and has a high mortality rate. It may cause tissue and organ necrosis with extensive intravascular coagulation. Deaths are usually caused by multisystemic thrombosis or septic shock. It is vital to find the etiological cause quickly and start treatment. Purpura fulminans can rarely occur after drug use. Since lamotrigine also causes serious skin reactions, rashes that occur after starting the drug should be followed carefully. Here we present a case of purpura fulminans, which developed rashes 20 days after lamotrigine was initiated, but was caused by infection, not lamotrigine. This case is presented to draw attention to the fact that lamotrigine should not be blamed for every rash seen, even though it causes serious skin reactions.

Keywords Lamotrigine; Purpura fulminans; Streptecoccus pneumonia 


\section{GIIRIș}

İlaç reaksiyonlarında en çok suçlanan antiepileptik ilaçlar aromatik yapıya sahip olanlardır. Bunlar fenitoin, lamotrijin, karbamazepin, okskarbazepin, eslikarbazepin, fenobarbital, primidon ve zonisamid gibi ilaçlardır. İmmun aracılı ilaç reaksiyonlarına genellikle kullanımları daha yaygın olan antibiyotikler neden olmaktadır. Antiepileptik ilaçlar sık olmamakla birlikte ilaca bağlı aşırı duyarlılık reaksiyonuna neden olabilirler. ${ }^{1}$ İlaca bağlı ortaya çıkan izole cilt reaksiyonlarının küçük bir kısmı yaşamı tehdit eden alerjik reaksiyonlara dönüşür. ${ }^{2}$ Deri döküntüsü, lamotrijin kullanımı sırasında ortaya çıkabilen ve tedavinin değiştirilmesine neden olan en önemli yan etkilerden biridir. ${ }^{3}$

Purpura fulminans (PF) nadir görülen ve mortalitesi yüksek bir hastalıktır. PF, pıhtılaşma sistemini aktive ederek yaygın damar içi pıhtılaşmaya ve buna bağlı deri nekrozuna neden olan klinik bir tablodur. ${ }^{4}$ PF' de lökoklastik vaskülit genellikle görülmez. ${ }^{5}$ Lökoklastik vaskülitin etiyolojisinde ilaçlar, enfeksiyonlar, maligniteler, sistemik inflamatuar hastalıklar gibi birçok neden yer almaktadır. PF etiyolojisinde ise akut enfeksiyonlar (genellikle Neisseria meningitidis), protein $\mathrm{C}, \mathrm{S}$ eksikliği ve nedeni saptanamayan idiopatik grup yer almaktadır. İlaca bağlı olarak bildirilen nadir PF vakaları da bulunmaktadır., ${ }^{6,7}$ Burada lamotrijin başlandıktan 20 gün sonra vücutta yaygın döküntü nedeni ile ilaç aşırı duyarlılık reaksiyonu olarak dış merkezden sevk edilen hasta tanı ve tedavi yaklaşımı ile sunulmuştur.

\section{OLGU SUNUMU}

36 yaşında mental retardasyonu olan hasta vücutta yaygın döküntü ve genel durum bozukluğu nedeni ile hastanemize sevk edilmişti. Epilepsi tanısı ile valproik asit 1000 mg/gün kullanımı olan hastanın tedavisine nöbet kontrolü için üç hafta önce lamotrijin eklenmiş ve kademeli olarak $50 \mathrm{mg} /$ gün dozuna çıkılmıştı. Bir gün önce vücutta döküntülerin başlaması ve hızla artış göstermesi nedeni ile nöroloji uzmanına kontrole giden hasta Stevens-Johnson Sendromu (SJS) ön tanısı ile hastanemize sevk edilmişti.
Özgeçmiş; 25 yıldır epilepsi tanılı, 6 yıldır valproik asit kullanıyor. Soygeçmiş; özellik yok. Fizik muayenede; ekstremite distallerinde daha belirgin, yüzde, gövde de keskin sınırlı, peteşiyal, kırmızı-mor renkli ekimotik lezyonları mevcuttu (Resim 1, 2, 3). Oral ve genital mukozada lezyon yoktu. Vücutta ve mukozalarda epidermal ayrışma ve vezikülobüllöz bulgular yoktu. Sistemik muayenede; ateş 37,2 ${ }^{\circ} \mathrm{C}$, nabız $100 \mathrm{atım} / \mathrm{dk}$, tansiyon arteriyel 120/70 mmHg, solunum sayısı 18/dakika, oda havasında parmak ucu oksijen satürasyonu $\% 88$, solunum sesleri doğaldı. Nörolojik muayenesinde; genel durumu kötü, uykuya meyilli, mental retarde olduğu için oryantasyon-kooperasyonu değerlendirilemedi, ense sertliği yoktu, dört ekstremite hareketli, taban cildi refleksi bilateral ekstansör yanıt alınıyordu. Laboratuar verileri tablo 1'de verildi. Akciğer grafisi normaldi. Dermatoloji tarafından değerlendirilen hastada mevcut görünüm ve mukozal tutulum olmaması nedeni ile PF düşünüldü. Dahiliye kliniği tarafından değerlendirilen hastada laboratuar verileri ile klinik olarak sepsis ve dissemine intravasküler koagülasyon (DIC) düşünüldü. Hastada mevcut döküntüler, DIC kanıtı olan laboratuar verileri (düşük fibrinojen, trombosit, yüksek protrombin zamanı, aktive parsiyel tromboplastin zamanı, d-dimer, C-reaktif protein düzeyleri) olması PF' yi destekliyordu. Taraf1mızca hasta epilepsi yönü ile değerlendirildi ve etiyolojik nedenin ilaç olması ihtimaline yönelik lamotrijin tedavisi kesilerek tedavisine levetiresetam $500 \mathrm{mg} /$ gün eklendi. PF etiyolojisine yönelik idrar, kan ve balgam kültürleri alındı. Protein C ve S düzeyleri gönderildi, düşüktü. Meningeal irritasyon bulgusu olmadığı için lomber ponksiyon yapılmadı. Viral enfeksiyonlar için serolojik testlerin sonuçları (hepatit B, C, HIV) negatifti. Serum IgA, M ve G seviyeleri normaldi. Enfeksiyona yönelik meropenem 1 gr 2x1, DIC tablosu için taze donmuş plazma $2 \times 2$, fibrinojen ve hidrasyon başlandı. Enoksaparin sodyum kiloya göre doz hesaplanarak verildi. Anestezi yoğun bakıma alınarak tedavisine devam edildi. Yatışının üçüncü gününde solunum sıkıntısı gelişen hasta entübe edilerek takibine devam edildi. Hastanın balgam kültüründe Streptecoccus pneumonia üredi. Bu durum etiyolojik nedenin ilaç değil enfeksiyon olduğunu 
destekliyordu. Hasta yatışının onuncu gününde sepsis ve tromboza bağlı kaybedildi. Hasta yakınından olgunun bilimsel ortamda sunulması için bilgilendirilmiş onam formu alınmıştır.

\begin{tabular}{|c|c|}
\hline Parametreler & Sonuç \\
\hline Aspartat aminotransferaz & $396 \mathrm{U} / \mathrm{L}$ \\
\hline Alanin aminotransferaz & $250 \mathrm{U} / \mathrm{L}$ \\
\hline Gama glutamil transferaz & $175 \mathrm{U} / \mathrm{L}$ \\
\hline Laktat dehidrogenaz & $2738 \mathrm{U} / \mathrm{L}$ \\
\hline Kreatinin & $4,2 \mathrm{mg} / \mathrm{dL}$ \\
\hline Kan üre nitrojeni & $50,4 \mathrm{mg} / \mathrm{dL}$ \\
\hline Sodyum & $131 \mathrm{mmol} / \mathrm{L}$ \\
\hline Kalsiyum & $6,1 \mathrm{mg} / \mathrm{dL}$ \\
\hline Albümin & $2,6 \mathrm{~g} / \mathrm{dL}$ \\
\hline Troponin & $810 \mathrm{ng} / \mathrm{dL}$ \\
\hline Glukoz & $97 \mathrm{mg} / \mathrm{dL}$ \\
\hline D-dimer & $24500 \mathrm{ng} / \mathrm{mL}$ \\
\hline Fibrinojen & $79 \mathrm{mg} / \mathrm{dL}$ \\
\hline $\begin{array}{l}\text { INR (Uluslararası Nor- } \\
\text { malleștirilmiş Oran) }\end{array}$ & 3,1 \\
\hline $\begin{array}{l}\text { Aktive parsiyel tromboplastin } \\
\text { süresi }\end{array}$ & 39,2 \\
\hline Protein $\mathrm{C}$ & 40 \\
\hline Protein S & 58 \\
\hline Antitrombin 3 aktivitesi & 89 \\
\hline Hemoglobin & $13,3 \mathrm{~g} / \mathrm{dL}$ \\
\hline Trombosit & $80000 / \mu \mathrm{L}$ \\
\hline $\begin{array}{l}\text { Beyaz küre } \\
\text { Lenfosit } \\
\text { Nötrofil } \\
\text { Monosit }\end{array}$ & $\begin{array}{c}22000 / \mu \mathrm{L} \\
\% 25,8 \\
\% 71 \\
\% 1,9\end{array}$ \\
\hline C-reaktif protein & $248 \mathrm{mg} / \mathrm{L}$ \\
\hline Balgam kültürü & Streptecoccus pneumonia \\
\hline İdrar & Eser protein \\
\hline
\end{tabular}

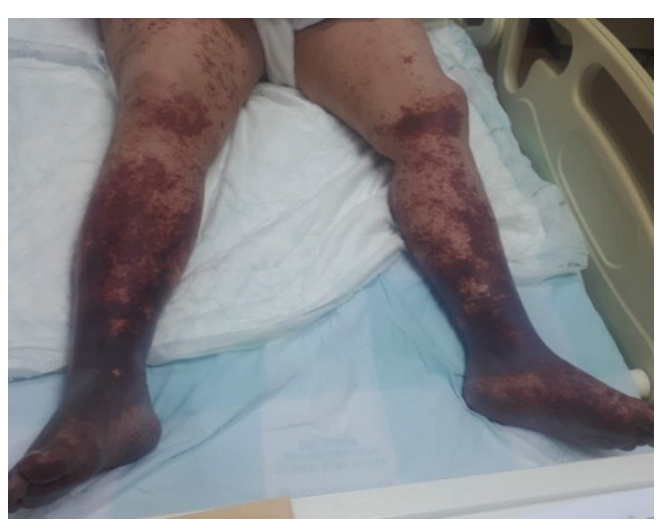

Resim 1: Alt ekstremitede distallerde belirgin, ayak tabantnın da tutulduğu, ăg şeklinde, mor renkli, peteşiyal ve ekimotik lezyonlar izleniyor.

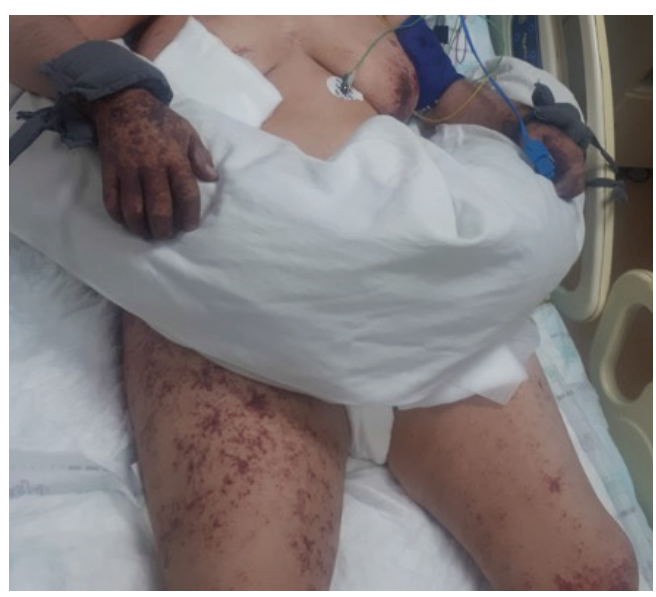

Resim 2: Üst ekstremitede distallerde belirgin, avuç içinin de tutulduğu, ekstremite proksimalleri ve gövde de ăg şeklinde parçal, mor renkli, peteşiyal ve ekimotik lezyonlar izleniyor.

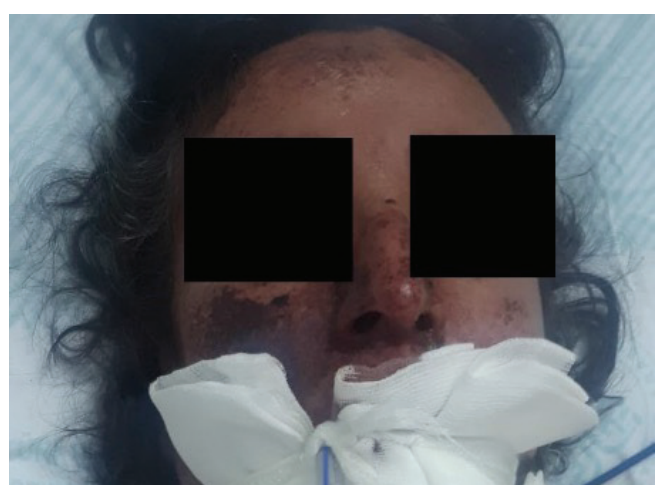

Resim 3: Yüzde alın, burun ve yanaklarda ă̆ şeklinde parça$l$, mor renkli, peteşiyal ve ekimotik lezyonlar izleniyor. 


\section{TARTIŞMA}

Lamotrijin ile ilgili cilt reaksiyonları genellikle hızlı titrasyon ve valproik asit ile kombinasyonu sırasında gözlenmektedir. Lamotrijin kullanımı sonrasında görülebilen SJS ve toksik epidermal nekroliz hastalarda yaşamı tehdit edebilmektedir. Bu klinik tablolarda hastaların \%90’ dan fazlasında ağız ve genital mukozalarda tutulum izlenmektedir. ${ }^{8}$ Faringeal mukoza neredeyse tüm hastalarda etkilenir. ${ }^{9}$ İlaca bağlı döküntüler genellikle ilacın başlamasını takip eden ilk 8 hafta içinde görülmektedir. Hastamızda döküntülerin ilaç başlandıktan üç hafta sonra ortaya çıkması ve beraberinde valproik asit kullanımının olması döküntülerin ilaç kaynaklı olabileceğini düşündürürken mukozal tutulumunun olmaması, DIC tablosunun olması klinik olarak PF' yi desteklemekteydi. PF yetişkinlerde sıklıkla Neisseria meningitidis enfeksiyonuna sekonder izlenirken hastamızda meningeal irritasyon bulguları olmadığı için lomber ponksiyon yapılmadı. PF’ ın nadir bakteriyel nedenlerinden biri olan Streptococcus pneumonia' nın balgam kültüründe üremesi ile etiyolojik neden gösterildi. Etiyolojik nedenin tesbit edilmesi ve hastanın genel durumunun kötü olması nedeni ile cilt biyopsisi yapılmadı. PF' nin ilaca bağlı olarak izlenmesi daha nadir olup etiyolojide enfeksiyon veya farklı bir neden saptanamayan hastalarda cilt biyopsisi yapılarak lökoklastik vaskülit gösterilmesi ile doğrulanabilmektedir.

Hastalarda tedavi açısından SJS ve PF ayırımı önemlidir. SJS daha çok ilaç kaynaklı olup tedavisinde steroid ve intravenöz immünglobulin kullanılırken, PF’ nin etiyolojisinde bakteriyel ve viral enfeksiyonlar sıklıkla izlenmekte ve kliniğe DIC eşlik etmektedir. PF tedavisinde altta yatan enfeksiyonun tedavisi, akut hemolitik tranfüzyon reaksiyonu için agresif hidrasyon, şiddetli kanama için kan transfüzyonu yapılmaktadır. Hastalara tedavide rutin antikoagülan önerilmeyip trombotik komplikasyon gelişmesi durumunda uygulanmaktadır. Kanamanın önlenmesine yönelik tedaviler ise hastanın trombosit sayısına ve fibrinojen düzeyine göre belirlenmektedir. Literatürde ilaçla ilişkili hipersensitivite vasküliti nedeniyle PF tanısı konu- lan hastanın steroide iyi yanıt vermesi ve takipte tamamen düzelmiş olması tedavide etiyolojik nedenin önemini göstermektedir. $^{7}$

Tedavideki ilerlemelere rağmen PF ile ilgili mortalite ve morbidite oranları yüksektir. ${ }^{4}$ Tedavi için etiyolojik nedenin erken tesbit edilmesi hayati öneme sahiptir. Lamotrijin kullanan hastalarda da farklı nedenlerle döküntülerin ortaya çıkabileceğini unutmamalıyız. 
Sakarya Tip Dergisi 2021;11(2):442-446

ŞiMȘEK ve Ark., Purpura Fulminansın Nedeni Lamotrijin mi

Kaynaklar

1. Alvestad S, Lydersen S, Brodtkorb E. Rash from antiepileptic drugs: influence by gender, age, and learning disability. Epilepsia 2007; 48:1360-1365.

2. Wang X-q, Lang S- $y$, Shi $X-b$, Tian $H-j$, Wang R-f, Yang F. Antiepileptic drug-induced skin reactions: a retrospective study and analysis in 3793 Chinese patients with epilepsy. Clinical neurology and neurosurgery 2012; 114:862-865.

3. Ben-Menachem E. New antiepileptic drugs and non-pharmacological treatments. Current Opinion in Neurology 2000; 13:165-170.

4. Warner PM, Kagan R, Yakuboff K, Kemalyan N, Palmieri TL, Greenhalgh DG, et al. Current management of purpura fulminans: a multicenter study. The Journal of burn care \& rehabilitation 2003; 24:119-126.

5. Ward KM, Celebi JT, Gmyrek R, Grossman ME. Acute infectious purpura fulminans associated with asplenism or hyposplenism. Journal of the American Academy of Dermatology 2002; 47:493-496.
6. Kosaraju N, Korrapati V, Thomas A, James B. Adult purpura fulminans associated with non-steroidal anti-inflammatory drug use. Journal of postgraduate medicine 2011; 57:145.

7. Okamura I, Nakamura Y, Katsurada Y, Sato K, Ikeda T, Kimura F. Successful corticosteroid treatment for purpura fulminans associated with quinolone. Internal Medicine 2016 55:3047-3051.

8. Letko E, Papaliodis DN, Papaliodis GN, Daoud YJ, Ahmed AR, Foster CS. Stevens-Johnson syndrome and toxic epidermal necrolysis: a review of the literature. Annals of Allergy, Asthma \& Immunology 2005; 94:419-436.

9. de Prost N, Mekontso-Dessap A, Valeyrie-Allanore L, Van Nhieu JT, Duong TA, Chosidow $O$, et al. Acute respiratory failure in patients with toxic epidermal necrolysis: clinical features and factors associated with mechanical ventilation. Critical care medicine 2014; 42:118-128. 